\title{
ESCLARECIMENTO E DOMINAÇÃO MASCULINA
}

\author{
Patrícia da Silva Santos ${ }^{1}$
}

Resumo: O objetivo deste artigo é interpretar o livro Dialética do esclarecimento e seus principais argumentos, considerando a dominaçấo masculina que perpassa a racionalidade moderna. Para isso, sugere-se uma interpretação acerca do entrelaçamento entre mito e esclarecimento, durante o processo de civilização ocidental, indicando que os argumentos de Adorno e Horkheimer tomam a modernidade como um projeto fundamentalmente masculino.

Palavras-chave: Esclarecimento. Civilização. Dominação masculina. Natureza.

Não sei o que estou escrevendo: sou obscura para mim mesma. Só tive inicialmente uma visão lunar e lúcida, e então prendi para mim o instante antes que ele morresse e que perpetuamente morre. Não é um recado de ideias que te transmito e sim uma instintiva volúpia daquilo que está escondido na natureza e que adivinho.

Clarice Lispector

\section{INTRODUÇÁO}

No diagnóstico-chave do livro Dialética do esclarecimento, destaca-se a constatação desconcertante de um entrelaçamento entre mito e esclarecimento e o argumento de que a civilização repousa em uma dominação de tripla dimensão: da natureza interna, da natureza externa e de outros homens. Nesse sentido, quando se toma a dominação como elemento central do processo civilizatório, não há como fugir ao fato de que violência e renúncia estão na base da nossa formação cultural, da nossa racionalidade, das nossas instituiçôes e da nossa subjetividade. Por medo, para autoconservar-se, os seres humanos foram

${ }^{1}$ Professora do Programa de Pós-Graduação em Sociologia e Antropologia (PPGSA) da Universidade Federal do Pará (UFPA/Belém), Belém, PA - Brasil. (DD https://orcid.org/0000-0002-1266-1311 E-mail: patricia215@gmail.com

http://doi.org/10.1590/0101-3173.2020.v43n3.23.p313

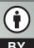

This is an open-access article distributed under the terms of the Creative Commons Attribution License. 
se constituindo a partir de renúncias aos instintos internos e da dominação do ambiente externo - tendo a racionalidade como principal instrumento.

Contudo, os indivíduos modernos não aparecem como portadores igualmente dotados da razão instrumental que teria triunfado, ao longo do processo histórico de desenvolvimento da civilização ocidental. Seu portador por excelência, no texto de Adorno e Horkheimer, é o "burguês" - que talvez possamos traduzir, em linguagem pós-colonial contemporânea, para o homemeuropeu-branco. É claro que também o burguês precisa subjugar sua natureza interna para poder ocupar tal posto. Porém, além disso, como principal portador e suporte [Träger] da razão moderna, no seu caso, a dominação da natureza interna está ainda mais intensamente acompanhada da dominação de outros seres humanos.

Neste artigo, importa explorar a dimensão de gênero própria a essas relaçóes assimétricas constitutivas da razão moderna. Grosso modo, o objetivo será delinear as especificidades da forma como as mulheres tomaram parte no processo de constituição da civilização, em conformidade com os argumentos de Adorno e Horkheimer. Nesse sentido, a intenção éler o livro e seu diagnóstico central, em função dessa ótica de gênero, explorando as inúmeras passagens em que o texto se vale das desigualdades entre homens e mulheres, a fim de apontar o quanto elas também estáo enraizadas em uma razão instrumental.

\section{Argumentos gerais da Dialética do Esclarecimento}

Inicialmente, vale recuperar alguns aspectos do diagnóstico geral do livro. A dominação tripla - dos impulsos internos, da natureza externa e de outros seres humanos - exposta na Dialética do esclarecimento, apoia-se numa perspectiva do mundo social que leva em conta tanto domínios subjetivos como sociais (vale dizer: a relaçáo com o ambiente e com os outros seres humanos). Para estabelecer essa estrutura complexa de dominação, os autores do livro combinaram argumentos da tradição marxista à psicanálise freudiana, em uma visada ampla a respeito do processo civilizatório ocidental.

Basicamente, na crítica radical feita por Adorno e Horkheimer à reificação, argumenta-se que "o mito já é esclarecimento e o esclarecimento acaba por reverter à mitologia” (ADORNO; HORKHEIMER, 1985, p. 15). Por certo, em conexão crítica com a tradição marxista, a dominação social e capitalista - a luta de classes - continua sendo o nexo central a ser destrinchado 
(por isso, o livro apresenta-se como diagnóstico do presente, como tentativa de entender o mundo administrado coevo), entretanto, buscam-se as origens para uma interpretação do mundo capitalista moderno também por meio da constatação de que a configuração social contemporânea incluiu uma dominação da natureza interna que precede o capitalismo como sistema econômico.

Assim, juntamente com a crítica à dominação atual da mercadoria, os autores recorrem ao texto da Odisseia como uma espécie de alegoria, para reconstruir o processo ocidental de formação do indivíduo, demonstrando o quanto ele se apoia em sucessivos processos de repressão da natureza, para a eliminação de tudo o que náo se deixa classificar, de todo elemento "náo-idêntico". A concepção de racionalidade mobilizada pelos autores incorpora, nesse sentido, elementos sociológicos e psicanalíticos, combinando dominação social e autoconservação: "No sentido mais amplo do pensamento, o esclarecimento tem perseguido sempre o objectivo de livrar os homens do medo e de investi-los na posição de senhores" (ADORNO; HORKHEIMER, 1985, p. 19).

Por um lado, explorando teses freudianas, Adorno e Horkheimer apontam a dimensão violenta presente na cultura, a qual, para impor-se, exige renúncias: "[...] a cultura está construída sobre a renúncia a impulsos." (FREUD, 1929/2010, p. 101, tradução modificada). Por outro, indicam também que, nesse processo de dominação da natureza interna, os indivíduos também se dominam uns aos outros e, além disso, subjugam o ambiente externo.

Nesse sentido, uma das imagens mais poderosas dentre as retiradas da Odisseia é a de Ulisses amarrado ao mastro, para poder usufruir do canto das sereias, sem se entregar totalmente a elas (pois se atirar ao mar em sua direção seria fatídico, implicaria a dissolução do eu), enquanto seus companheiros estão com os ouvidos tapados com cera, trabalhando diligentemente, para que o barco avance mar afora (HOMERO, 2008, p. 215-239). Vale ainda notar que, na imagem, uma divisão social do trabalho já está presente, com a possibilidade de que o burguês se aproxime, mesmo que de maneira precária, do prazer, ao passo que os trabalhadores permanecem sujeitos ao movimento mecânico, presos à ignorância completa do poder de sedução da arte representado pelo canto das sereias. A tripla dominação faz-se presente: Ulisses dominando seus impulsos, diante da sedução irresistível desse canto, dominando igualmente a natureza hostil do meio ambiente (o oceano) e, por fim, dominando seus companheiros. 
Além disso, há, nessa imagem, outro elemento relevante do ponto de vista da presente proposta de interpretação: como argumenta Rebecca Comay (2006, p. 45), a voz das sereias é, simultaneamente, "[...] uma voz da natureza, uma voz do prazer, uma voz do passado e, sim, uma voz de mulheres". O perigo de dissolução fatal que essa voz representa não se limita à desagregação da identidade rígida do burguês, mas também de sua "masculinidade", na medida em que significaria a redução do seu portador a "um monte de ossos" (COMAY, 2006, p. 45).

De todo modo, até aqui, os apontamentos acerca da dominação e sua relação com a cultura ocidental, em linhas gerais, encerram ainda o argumento geral presente no livro Dialética do esclarecimento - e não é meu objetivo explorá-lo dessa maneira ampla. Concentremo-nos no cruzamento de gênero que faz parte do pano de fundo das concepçôes dos autores. Lido por esse viés, o livro de Adorno e Horkheimer oferece elementos recorrentes acerca do sexismo inerente à razão moderna.

Ao entrarmos propriamente nessa reflexão, é oportuno ter em mente uma imagem da redação desse livro capital para o século XX, pois talvez ela também sirva para entendermos os elementos aporéticos dessa crítica à razão (reconhecidos pelos próprios autores), a qual se realiza precisamente a partir do pensamento esclarecido - portanto, incorporando também seus nexos controversos. Refiro-me ao fato de que o texto de Dialética do esclarecimento é, em sua maior parte, resultado das anotaçóes literais feitas por Gretel Adorno de conversas entre seu marido e Horkheimer, no período que vai de 1942 a $1944^{2}$ (WIGGERHAUS, 2008, p. 363). São dois homens que realizam aqui a reflexão intelectual, enquanto à mulher resta o trabalho mecânico de registrar o pensamento masculino - ainda que crítico, esse pensamento náo se descola totalmente dos limites da razão ocidental analisada nesse livro e suas conformações sociais, porque ele está nela inserido e, consequentemente, preso aos seus desígnios. ${ }^{3}$

${ }^{2}$ Um biógrafo de Adorno registra que a divisão do trabalho, no casamento de Adorno e Gretel, transcorreu conforme o "modelo tradicional", tornando-se ela (doutora em química) responsável pela organização e condução da casa (MÜLLER-DOOHM, 2011, p. 348). "No momento em que Adorno tinha se familiarizado com a nova situação de convivência matrimonial e Gretel começou a tomar para si as coisas práticas do cotidiano, ele estimulou os colaboradores de Nova Iorque do instituto a conduzir um estudo sobre a 'psicologia da mulher burguesa atual'” (MÜLLER-DOOHM, 2011, p. 356-357).

3 Tais limites são pontuados no prefácio de Adorno e Horkheimer: "A aporia com que nos defrontamos em nosso trabalho se revela assim como o primeiro objeto que tivemos que investigar: a autodestruição do esclarecimento. Não alimentamos dúvida nenhuma - e nisso reside nosso petitio principii - de 
Para que possamos refletir acerca das críticas à dominação masculina expostas no texto, é importante ter em mente essas contingências históricas, que estão na base do empreendimento proposto por essa corrente teórica.

\section{RAZÃo SEXISTA}

Por conta da complexa relação de dominação existente na cultura ocidental, as mulheres aparecem incorporadas à "sociedade burguesa", de uma maneira ambígua. A fim de demonstrar como chegaram a ocupar essa posição, no presente histórico, conforme ilustrado em algumas passagens abaixo, o tempo todo, no livro, indica-se que elas não só precisaram passar por esses processos de dominaçáo da natureza interna, mas também foram submetidas ao domínio dos homens, dado que eles são os portadores efetivos da racionalidade ocidental moderna. É por isso, por exemplo, que os autores da Dialética do esclarecimento afirmam que os "conceitos filosóficos" por meio dos quais Platão e Aristóteles expóem o mundo, embora se apresentem sob a "pretensão de validade universal", carregam um inexorável caráter excludente, que é, ao mesmo tempo, sexista, geracional e classista: esses conceitos "[...] refletiam com a mesma pureza as leis da física, a igualdade dos cidadãos plenos e a inferioridade das mulheres, das crianças e dos escravos." (ADORNO; HORKHEIMER, 1985, p. 35 - tradução modificada).

É nesse sentido que o episódio da Odisseia que expóe o encontro de Ulisses e seus companheiros com Circe é mobilizado por Adorno e Horkheimer, para elaborar as ideias paradoxais de "sedução irresistível" e de "impotência" que concernem às mulheres, na sociedade moderna. No texto grego, Ulisses encontra a deusa hetaira Circe, depois que ela havia transformado seus companheiros em porcos. Ele também é seduzido por ela, porém, prevenido por Hermes, a ludibria e não ingere o líquido mágico que o faria obedecer às suas ordens. É, assim, mobilizando a "astúcia da dominação" (ADORNO; HORKHEIMER, 1985, p. 55), que Ulisses pode se utilizar da violência, para dominar Circe. Apenas depois de conseguir dela a promessa de que libertará seus companheiros, ele consente praticar sexo com ela (HOMERO, 2008,

que a liberdade na sociedade é inseparável do pensamento esclarecedor. Contudo, acreditamos ter reconhecido com a mesma clareza que o próprio conceito desse pensamento, tanto quanto as formas históricas concretas, as instituiçôes da sociedade com as quais está entrelaçado, contém o germe para a regressão que hoje tem lugar por toda parte. Se o esclarecimento não acolhe dentro de si a reflexão sobre esse momento regressivo, ele está selando seu próprio destino." (ADORNO; HORKHEIMER, 1985 , p. 13 - tradução modificada). 
p. 147-177). A luta por autoconservaçáo apoia-se nesse "recurso do eu para sair vencedor" que é a astúcia (ADORNO; HORKHEIMER, 1985, p. 57). Destarte, a razão vai se constituindo historicamente, porém, o que se pode ler a contrapelo no argumento dos autores é que essa razão não é assexuada.

No episódio relativo a Circe já estaria presente uma associação central das desigualdades de gênero que persistem em nossas sociedades ocidentais: "desejo e comando". Tal par apresenta-se também em diferentes âmbitos contemporâneos das relaçôes de gênero: nas relaçôes sexuais, no âmbito das representaçóes presentes na indústria cultural, no próprio matrimônio. Para Adorno e Horkheimer (1985, p. 77), "[...] o casamento pertence certamente à rocha primeira do mito na base da civilizaçâo", porque ele incorpora aquela dimensão da dominação sobre outros seres humanos, dado que, nele, "a mulher continua a ser impotente na medida em que o poder só lhe é concedido pela mediação do homem” (ADORNO; HORKHEIMER, 1985, p. 74). No casamento de Ulisses com Penélope, Adorno e Horkheimer (1985, p. 74) reconhecem um estágio desenvolvido da "objetividade da instituição patriarcal" do matrimônio. Nessa interpretação da Odisseia, os autores encontram a pré-história das relaçóes de gênero contemporânea.

$\mathrm{Na}$ sociedade burguesa, o vínculo entre mito e esclarecimento se expressa por meio do casamento, a partir da conformaçáo de uma "imagem enigmática” na figura da mulher: sedução irresistível e impotência se combinam, nessa imagem. É como se o casamento propiciasse aos homens uma aproximação à natureza (representada pela mulher) que envolve subjugação, mesmo que se apresente como reconciliação - por isso, essa forma de laço social, institucionalizada através de um contrato, é tão relevante na compreensão do nexo existente entre racionalidade moderna e dominação de gênero. Adorno e Horkheimer elaboram essa questão, especialmente a partir da figura de Circe. Se, inicialmente, a poderosa sedutora logra transformar os companheiros de Ulisses em porcos, os quais devem arrastar compulsivamente o nariz pelo chão e renunciar ao andar ereto, ao ceder às imposiçôes do herói homérico para poder viver com ele como sua companheira, Circe já se mostra "fraca, obsoleta e vulnerável" (ADORNO; HORKHEIMER, 1985, p. 74). A lógica da autoconservação de Ulisses prevalece sobre as forças da natureza irresistível, contribuindo para o desenvolvimento de uma razão enraizada em processos recorrentes de dominação.

A preocupação com a forma como o casamento se processa, na sociedade capitalista moderna, está muito presente na reflexão dos 
pensadores. Especialmente Adorno parece bastante interessado no problema. Exemplos disso estão em várias passagens de Minima Moralia, que foi escrito concomitantemente à redação de Dialética do esclarecimento e tinha como principal mote apontar os nexos cotidianos do diagnóstico feito nesse último livro. Tendo em vista essa vinculação entre os dois textos, vale retomar um dos excursos de Minima Moralia, no qual há a constatação de que um casamento só seria digno, caso as pessoas nele envolvidas tivessem suas vidas independentes, "sem a fusão derivada da comunidade de interesses economicamente imposta" (ADORNO, 2008, p. 27).

Aqui, como em todos os outros argumentos, também se destaca a crítica ao sistema econômico capitalista, dado que seus interesses promovem inexoravelmente o aviltamento dos indivíduos e de suas relaçóes sociais. A dominação masculina e sua racionalidade intrínseca não podem ser entendidas de maneira separada da dominação econômica. Ao lidar com o episódio de Circe, Adorno e Horkheimer destacam também esse nexo, indicando como o casamento assume a forma de uma troca contratual, em que ambos realizam renúncias, mas de forma desigual - tal qual ocorre nas trocas econômicas. Assim, a renúncia inicial de Ulisses à sedução de Circe é paga por ela com o prazer que havia sido desdenhado. Porém, antes, estabelece-se o contrato de submissão, por meio do juramento dos "bem-aventurados", proferido por Circe:

$\mathrm{O}$ juramento deve proteger o homem da mutilação, da vingança para a proibição da promiscuidade e para a dominação masculina, que, no entanto, enquanto renúncia permanente ao instinto, ainda realizam simbolicamente a automutilação do homem (ADORNO; HORKHEIMER, 1985, p. 74).

É nesse sentido que, no livro Dialética do esclarecimento, há a afirmação de que a sedução é incorporada às relaçóes entre os gêneros sob o manto da razão ocidental, mas essa dimensão libidinal dos impulsos humanos precisa, antes, passar pelo filtro da dominação, de tal modo que, seja sob a imagem da "prostituta”, seja sob o ideal da "esposa” dona de casa, a participação da mulher no mundo patriarcal é posta a serviço da "autoconservação masculina". Desse modo, as mulheres atualizariam o texto homérico em suas atividades cotidianas: assim como Circe, que, depois de passar um ano vivendo com Ulisses, utiliza seus poderes para prever os perigos que ele enfrentaria em sua viagem e orientá-lo acerca das precauçôes necessárias para sua superação, a atuação das mulheres, na sociedade moderna, estaria sempre vinculada a um imenso 
cuidado, para que o homem seja preservado física e psicologicamente. Outra imagem cotidiana de Minima moralia expressa bem isso: "O tirano doméstico enverga o sobretudo com a ajuda pressurosa da esposa." (ADORNO, 2008, p. 168). Esse problema também é recorrente na Dialética do esclarecimento:

A divisão do trabalho imposta pelo homem foi-lhe [para a mulher] pouco favorável. Ela passou a encarnar a função biológica e tornou-se o símbolo da natureza, cuja opressão é o título de glória dessa civilização. Durante milênios os homens sonharam com o domínio ilimitado da natureza e com a transformação do cosmo num infinito território de caça. É para isso que se voltavam as ideias das pessoas numa sociedade de homens. Era este o sentido da razão de que se ufanavam (ADORNO; HORKHEIMER, 1985, p. 231).

Outro ponto a ser matizado é que todas as reflexôes de Adorno e Horkheimer a respeito da mulher possuem conexáo com sua perspectiva geral em relação ao capitalismo como o sistema econômico que coroou o "entrelaçamento entre mito e esclarecimento". Nesse sentido, os autores defendem que, no decorrer do processo civilizacional, a servidão da mulher foi transfigurada pelo cristianismo, por meio do casamento. Anteriormente, haveria ainda a ideia de um amor romântico entre os gêneros, o qual culminava em uma reconciliação forçada, na qual "a mulher parecia assumir livremente a derrota, o homem a conceder-lhe a vitória" (ADORNO; HORKHEIMER, 1985 , p. 102). Porém, já na sociedade industrial ${ }^{4}$, o "amor é faturado" e a hierarquia dos gêneros é filtrada pela "ordenação masculina da propriedade". O contrato levado a cabo pelo casamento é só mais um aspecto da interposiçáo da propriedade também no âmbito das relaçóes amorosas.

Por isso, as transformaçóes históricas que perpassam as relações de propriedade e a produção afetam também as concepções de família e, respectivamente, de gênero. Para Adorno e Horkheimer, o desaparecimento da pequena propriedade faz com que a família deixe de ser a célula da sociedade,

${ }^{4} \mathrm{O}$ propósito de Adorno e Horkheimer, ao reconstruir o processo de formação da razão ocidental, não pode ser dissociado do presente histórico e, portanto, da forma burguesa dessa razão. Como argumenta Cohn, "uma versão contemporânea da crítica racional da razão [...] Deve portanto interrogar a razão respeitando todas as suas exigências intrínsecas, sem no entanto perder de vista que, sob a capa da razão sem mais, efetivamente está em cena a sua forma historicamente dominante, a razão burguesa." (COHN, 1998, p. 53) 
porque já não configura a base de vida econômica. Homens e mulheres passam a submeter-se prioritariamente ao mercado, ao assalariamento ${ }^{5}$ :

Nas primeiras fases do nomadismo, os membros da tribo têm ainda uma parte autônoma nas açóes destinadas a influenciar o curso da natureza. Os homens rastreiam a caça, as mulheres cuidam do trabalho que pode ser feito sem um comando rígido. Quanta violência foi necessária antes que as pessoas se acostumassem a uma coordenação tão simples como essa é impossível determinar (ADORNO; HORKHEIMER, 1985, p. 34).

Por meio dos violentos rumos do desenvolvimento da civilização ocidental, especialmente a "mulher profissional" é submetida a um processo intenso de "fungibilidade" ao sistema econômico capitalista ${ }^{6}$. No pensamento de Adorno, especificamente, a reflexão aparecia como uma crítica à ideia da "emancipação da mulher" via incorporação ao mercado. Sem a emancipação da sociedade, as mulheres, mesmo participando da esfera pública através do trabalho, continuam submetidas aos mecanismos patriarcais, embora já seja mais difícil a formulação dessa questão. É o que consta, por exemplo, na seguinte passagem de Minima Moralia:

É verdade que, pela dissoluçáo da economia competitiva "masculina" - liberal, pela participação das mulheres no emprego, no qual são tão independentes quanto os dependentes homens, pelo desencantamento da família e a abertura dos tabus sexuais, ela não é mais "aguda". Ao mesmo tempo, porém, a persistência da sociedade tradicional ocultou a emancipação da mulher. Pouca coisa é táo sintomática da decadência do movimento trabalhador como a sua indiferença a isso. [...] Ao invés de resolver a questão feminina, a sociedade masculina estendeu de tal modo o seu princípio que as vítimas nem mais conseguem formular a questão (ADORNO, 2008, p. 88).

\footnotetext{
${ }^{5}$ Nos anos 30, na Alemanha, uma feminista formulava essa questão da seguinte forma: “[...] e assim as mulheres respiram sob a pesada pressão de uma atmosfera na qual os limites 'naturais' e 'eternos' entre os sexos se confundem e se apagam, mas náo foram criadas novas ordens [...] $\mathrm{O}$ traço da era foi elevado apenas no sentido dos homens, para as mulheres foi, na verdade, prejudicial, porque 'suas' funçóes são roubadas, sem que, momentaneamente, outras lhes sejam dadas. As mulheres foram, de certo modo, libertas, mas ao mesmo tempo, foram desenraizadas." (RÜHLE-GERSTEL, 1972, p. 126-127).

6 Vale mencionar que essa constatação faz parte de um importante debate de vertentes do pensamento feminista contemporâneo, do qual Nancy Fraser é uma das interlocutoras proeminentes. Para Fraser, basicamente, o neoliberalismo foi capaz de absorver e reorientar a luta das mulheres por mais participaçáo na esfera pública da sociedade e do mundo do trabalho. Caberia ao movimento feminista fazer uma revisão a respeito de sua cota de responsabilidade em relação a esse processo (FRASER, 2013).
} 
Conforme o argumento da Dialética do esclarecimento, essa inclusão da mulher no mercado e na sociedade capitalista contemporânea é sempre levada a cabo, de sorte a preservar sua não individualização, como se ela existisse como "um exemplar da espécie", não como um sujeito de direitos, tal como prescrito pelo pensamento iluminista:

O homem dominador recusa à mulher a honra de individualizá-la. A mulher tomada individualmente é, do ponto de vista social, um exemplar da espécie, um representante de seu sexo e é por isso que ela, na medida em que está inteiramente capturada pela lógica masculina, representa a natureza, o substrato de uma subsunçáo sem fim na ideia, de uma submissão sem fim na realidade. A mulher enquanto ser pretensamente natural é produto da história que a desnatura (ADORNO; HORKHEIMER, 1985, p. 106).

Essas consideraçóes de Adorno e Horkheimer a respeito das mulheres como seres não totalmente individualizados, como o seriam os homens, foi precedida, no âmbito da teoria filosófica e social, por Georg Simmel - o qual, dentre os clássicos da teoria sociológica, foi aquele que mais lidou com essa questão das desigualdades de gênero (mesmo que não exatamente nesses termos, todavia, em conformidade com o léxico, os debates e os nexos históricos disponíveis na época). A associação é relevante, sobretudo se tivermos em mente dois aspectos. Primeiro, a circunstância de que Simmel efetivamente reservou um espaço central entre suas reflexôes para o problema (diferentemente de Adorno e Horkheimer ${ }^{7}$ ) - e é muito provável que Adorno, como leitor da obra simmeliana, tenha entrado em contato com tais discussóes. O segundo ponto refere-se ao fato de que Simmel abordou a temática, associando-a à discussão acerca da racionalidade moderna, do avanço da intelectualização e do cálculo - pontos importantes na discussão desenvolvida na Dialética do Esclarecimento. Com efeito, há um vínculo muito forte entre as reflexóes de Simmel a respeito da modernidade e suas consideraçóes a respeito das mulheres (LICHTBLAU, 1996, p. 292-314). Por volta da virada para o século XX, esse pensador argumentava que a modernidade contém um "princípio masculino" inerente: são os homens que formataram a racionalidade moderna, sua divisão do trabalho, seu modo de produção e sua objetividade, precisamente porque são eles quem tiveram uma participação ativa na esfera pública.

\footnotetext{
7 Embora seja possível ler as teses da Dialética do esclarecimento, por exemplo, sob a ótica das desigualdades de gênero, Adorno e Horkheimer não apresentam uma reflexão sistemática e centralizada nessa questâo.
} 
De acordo com Simmel (1995 p. 419), “[...] nossa cultura objetiva, com exceção de muitíssimo poucos domínios, é completamente masculina”. Em decorrência disso, a ideia moderna de indivíduo como um eu altamente diferenciado e encerrado em si mesmo só teria sido assimilada a contento pelos homens. Simmel (1985, p. 148) chega a afirmar que as mulheres seriam a expressão de uma "unidade pré-diferenciada", por isso, elas estariam mais atreladas ao "tipo genérico" [Gattungstypus] do que os homens. Em alguma medida, em conformidade com essas reflexões, é como se as mulheres não tivessem assimilado a "cultura objetiva" da modernidade, nem do ponto de vista da sua participaçáo social efetiva na esfera pública, nem de uma perspectiva subjetiva, ligada à identidade - é oportuno lembrar que o objetivo, do ponto de vista de Simmel, tem caráter indisfarçavelmente sexista.

De maneira próxima, guardadas as devidas distinçôes entre o pensamento simmeliano e o professado na Dialética do esclarecimento, Adorno e Horkheimer também apontam esse caráter masculino da razão ocidental. Embora esse não seja o tema central do livro, é possível acompanhar, no argumento relativo ao entrelaçamento entre mito e esclarecimento, uma discussão relativa à desigualdade de gênero, a qual passa justamente pelo caráter sexista da razão ocidental. A figura da mulher aparece ao longo da Dialética do esclarecimento, para destacar a dimensão de dominação que é inerente à constituição do indivíduo moderno, como subjetividades que tomam parte no processo civilizatório ocidental de uma maneira não propriamente ativa, mas sob o jugo de muita violência.

Quando se observam essas reflexóes com um olhar contemporâneo, depois de toda a discussão de vertentes de pensamento feminista que se esforçaram por desconstruir os essencialismos ligados à condição da mulher - como, por exemplo, a afirmação clássica e taxativa de que "não se nasce mulher, torna-se mulher" (BEAUVOIR, 1980, p. 9) - e, mais ainda, do feminismo pós-estruturalista, com suas críticas radicais a qualquer tentativa de normatização de identidades de gênero e mesmo de sexualidade (BUTLER, 1997, 2003), certamente é suscitada uma sensação de desconforto. Porém, apesar das formulaçóes aqui aparecerem em um registro muito taxativo e fixo, a respeito das identidades masculina e feminina ${ }^{8}$, é importante ressaltar que

\footnotetext{
${ }^{8}$ Deve-se recordar que o conceito de gênero que conhecemos hoje foi desenvolvido, inicialmente, por volta dos anos 1970: "Na sua utilização mais recente, o termo 'gênero' parece ter feito sua aparição inicial entre as feministas americanas, que queriam enfatizar o caráter fundamentalmente social das distinçōes baseadas no sexo. A palavra indicava uma rejeição do determinismo biológico implícito no uso de termos como 'sexo' ou 'diferença sexual'.” (SCOTT, 1995, p. 72).
} 
tanto Simmel ${ }^{9}$ como Adorno e Horkheimer remetem à história (de longo alcance, por certo) a conformação moderna dos indivíduos (sejam os homens, sejam as mulheres) - reforço a citação mais acima: "A mulher enquanto ser pretensamente natural é produto da história que a desnatura”.

Portanto, é a forma como os desenvolvimentos se deram historicamente que irá servir para a constituição da individualidade masculina e da alegada pouca diferenciação das mulheres - embora, no caso desses autores, se trate de uma história de longa duração. Esses desdobramentos se deram por meio de inomináveis violências. Em uma passagem de Minima moralia, Adorno afirma de forma ainda mais inequívoca que "o caráter feminino e o ideal de caráter segundo o qual ele é modelado são produtos da sociedade masculina”, mesmo quando se ressalta a pretensa natureza intacta da mulher, esta constitui uma natureza que ressurge, deformada, como seu oposto: "Aquilo que no nexo universal de ofuscação burguês se diz natureza não passa da marca da ferida da mutilação social" (ADORNO, 2008, p. 91).

Além disso, especificamente no caso de Adorno, é necessário frisar esse aspecto do distanciamento em relação a uma essencialização dos papéis de gênero, pois a temática da identidade como algo "não-idêntico", como um papel social ou uma função de caráter não normativo, sempre esteve presente em suas reflexôes - e elas valem, certamente, para as identidades de gênero:

[...] já no próprio conceito de função ou papel, derivado do teatro, prolonga-se a náo-identidade dos seres humanos consigo mesmos. Isto é, quando a função é convertida em um padrão social, por essa via se perpetua também que os homens não são aqueles que eles mesmos são, portanto que eles são não-idênticos. Considero repugnante a versão normativa do conceito de papel, e é preciso contrapor-se a ele com todo o vigor. Mas de um ponto de vista fenomenológico, portanto como descriçáo de uma situação de fato, ele é procedente (ADORNO, 2006, p. 178).

Nesse sentido, penso que conectar a reflexão de Adorno e Horkheimer à discussão prévia de Georg Simmel a respeito da modernidade de princípio masculino é relevante, porque, na Dialética do esclarecimento, trata-se, em grande parte, de apontar a gênese do indivíduo moderno, seu caráter irreconciliado em relação à natureza, sua constituição fixa da identidade, ainda que presa a

\footnotetext{
9 No caso de Simmel, é possível perceber certa ambiguidade em sua argumentação a respeito das desigualdades entre homens e mulheres. Conforme argumenta Bächi (2003), seu pensamento foi gradativamente concedendo mais espaço às instituiçôes e à dimensão sócio-histórica na conformação de gênero; de todo modo, não pode livrar-se completamente de essencialismos.
} 
uma racionalidade instrumental. Em Simmel, está muito claro que o típico indivíduo moderno, portador de uma razão totalmente submetida a fins, é um homem ${ }^{10}$. Muitas passagens da Dialética do esclarecimento também sugerem que a dominação da natureza e do mundo mítico, ao preço de renúncias e do cálculo racional, foi encaminhada por indivíduos do gênero masculino.

Assim, a despeito do incômodo causado pela leitura de certas passagens do texto de Adorno e Horkheimer, onde é ressaltada uma maior aproximação da mulher à natureza, a ideia central é que a mulher (assim como os loucos, as crianças, os homossexuais, os negros ou quaisquer etnias não europeias, poderíamos acrescentar) comporta dimensôes não totalmente compatíveis com a razão (masculina), tal qual ela foi historicamente desdobrada e, por isso, é difícil seu enquadramento no esforço classificatório dessa razáo ocidental. Isso as coloca em uma situação subalterna, mas também representa a sua possibilidade de resistência. Para Andrew Hewitt (2006, p. 76ss.), é justamente porque os homens recusam às mulheres o "privilégio da individualização" que elas são dotadas de uma potência positiva contra a racionalidade instrumental moderna. De acordo com essa possibilidade específica de interpretação, como não totalmente individualizadas em conformidade com a lógica instrumental masculina, as mulheres encerrariam a possibilidade, ainda que utópica, de superação de tal lógica.

Porém, apesar dessa dimensão utópica da situação de relativo desencaixe das mulheres no âmbito da racionalidade moderna, o que efetivamente ocorre é que tal desencaixe é posto a serviço da dominação masculina:

A explicaçáo do ódio contra a mulher, enquanto criatura mais fraca em termos de poder físico e espiritual e marcada na testa pelo estigma da dominação, é a mesma do ódio aos judeus. Nas mulheres e nos judeus é fácil ver que há milênios não exercem nenhuma dominação. Eles vivem, embora fosse possível eliminá-los, e seu medo e fraqueza, sua maior afinidade com a natureza em razão da pressão incessante a que estão submetidos, é seu elemento vital. Isso irrita e leva a uma fúria cega o homem forte, que paga sua força com um intenso distanciamento da natureza e deve eternamente se proibir o medo (ADORNO; HORKHEIMER, 1985, p. 106).

10 "[...] a mistura ingênua dos valores masculinos com os valores] é sustentada por relaçôes de poder históricas que se expressam logicamente no fatídico duplo sentido do conceito de 'objetivo' [sachlich]: o objetivo aparece como a ideia puramente neutra, na mesma medida sobre as unilateralidades masculino-feminino; mas agora o 'objetivo' é também a forma especial de realizaçôes que corresponde ao modo de ser especificamente masculino.” (SIMMEL, 1995 p. 430). 
A conexão entre machismo e antissemitismo, que aparece na passagem, se processa por meio de uma interpretação psicanalítica. Sob a forma de ódio e fúria, o homem projeta tanto nos judeus como nas mulheres o sofrimento que advém da dominação de sua natureza interna. Parece-lhe insuportável que o judeu e a mulher continuem a exibir "sua maior afinidade com a natureza" e a espelhar aquilo que ele se esforça para reprimir. A reflexão freudiana a respeito do mecanismo de projeção parece estar pautando teoricamente a citação acima, tendo em vista o que se dá, para Freud (1973, p. 303), na projeçáo:

Uma percepção interna é reprimida e, para substituí-la, seu próprio conteúdo, depois de experimentar certa deformaçáo, volta como percepção de fora para a consciência. [...] Quando não procuramos em nós mesmos as causas para certas sensaçōes, como fazemos com outras, mas as transferimos para o exterior, esse processo normal também merece o nome de uma projeção.

Nesse caso, Freud indica que a projeção não é um mecanismo apenas em situaçôes patológicas, mas também no caso de "processos normais". Segundo Adorno e Horkheimer, é perfeitamente possível reconhecer tal mecanismo em processos sociais recorrentes, como esse relativo ao antissemitismo e ao machismo. Por conseguinte, há, simultaneamente, processos psíquicos e sociais interagindo, para que a dominação masculina, portadora típica do "esclarecimento", se interponha. Como apontam os exemplos elencados, Adorno e Horkheimer lançam mão tanto do materialismo histórico como da psicanálise para elaborar esse processo. $\mathrm{O}$ que torna o argumento complexo é o fato de que tais elementos são sempre combinados entre si: troca e sacrifício foram se constituindo de maneira bastante intrincada, ao longo do processo de constituição da racionalidade ocidental, conforme consta em passagem sintomática: "[...] se a troca é a secularização do sacrifício, o próprio sacrifício já aparece como o esquema mágico da troca racional" (ADORNO; HORKHEIMER, 1985, p. 57). É por essa via que os autores interpretam a constituição de subjetividades pautadas em sucessivos processos de dominaçáo de distintas dimensôes, os quais culminaram nos "indivíduos ofuscados" (COHN, 1998), que operam as trocas capitalistas contemporâneas. Mas há sempre esse subtexto que insere o "homem burguês" como o portador por excelência da racionalidade que foi sendo desenvolvida, ao longo desses processos. 
O excurso intitulado "O homem e o animal" traz também diferentes reflexões acerca das mulheres. Inicialmente, há a constatação de que a razão é o elemento que diferencia o homem do animal, na história europeia. Essa ausência de razão é o que torna os animais criaturas malditas, as quais "recorda $[\mathrm{m}]$ uma desgraça infinita ocorrida em tempos primitivos" (ADORNO; HORKHEIMER, 1985, p. 231). De todo modo, é às mulheres que cabe a solicitude pelo animal, fato que se apoia na perspectiva mais geral de que as mulheres, que

[...] não tiveram nenhuma participação independente nas habilidades que produziram essa civilização, [devem ocupar-se da esfera do cuidado.] Ela não produz, mas cuida dos que produzem, monumento vivo dos tempos há muito passados da economia doméstica fechada" (ADORNO; HORKHEIMER, 1985, p. 231).

Nesse ponto, os autores tocam de novo em um tema caro a muitas vertentes do pensamento feminista, a saber: a ideia de que a civilização ocidental é fruto da atuação masculina, embora às mulheres sejam reservadas tarefas para a preservação dessa modernidade de caráter eminentemente sexista ${ }^{11}$. Por conta do não enfrentamento do mundo hostil, com o intuito da dominação por parte da mulher, ela consequentemente "não é sujeito", não entrou para a história, permaneceu presa aos desígnios míticos da natureza.

Vale mencionar que, posteriormente, esse será um dos grandes pontos da discussão desenvolvida por Seyla Benhabib, uma feminista representante da teoria crítica. Na mesma direção apontada por Adorno e Horkheimer, ela pontua que a distinção entre esfera pública e privada "serviu para confinar mulheres em esferas de atividade tipicamente femininas, como trabalho doméstico, reprodução, nutrição e cuidado com crianças, doentes e idosos, ao domínio 'privado' e mantê-las fora da agenda pública no Estado liberal” (BENHABIB, 1992, p. 108). De um lado, teria ficado estabelecido o domínio moral centrado em questôes de justiça, as quais se realizam na historicidade da esfera pública; de outro, a esfera privada relacionada à questão da vida boa,

\footnotetext{
${ }^{11}$ Já apontei a reflexão desenvolvida por Georg Simmel, que vai nessa direção. Lembro, ainda, discussōes mais contemporâneas levadas a cabo pela cientista política Carole Pateman, a qual efetiva uma leitura das teorias contratualistas do ponto de vista do "contrato sexual": tomando também a dicotomia público/ privado, a autora argumenta que o estabelecimento do "indivíduo universal" instituiu a sociedade civil e postergou uma posição peculiar para as mulheres, de forma que elas são tanto objeto do contrato como parte contratante, na medida em que tomam parte apenas na "esfera privada" da "sociedade civil". "O contrato social é uma história de liberdade; o contrato sexual é uma história de sujeição. O contrato original cria ambas, a liberdade e a dominação" (PATEMAN, 1993, p. 16).
} 
ou seja, a questôes não universalizáveis, não passíveis de discussão pública. De acordo com Benhabib (1987, p. 97),

[...] a desistoricização do domínio privado significa que, enquanto o ego masculino celebra sua passagem da natureza para a cultura, do conflito para o consenso, as mulheres permanecem num universo interminável, condenadas a repetir os ciclos da vida.

$\mathrm{Na}$ crítica radical que Adorno e Horkheimer fizeram à razão ocidental, essa passagem dos homens para o domínio da cultura, do consenso e da história, foi feita às custas da dominação das mulheres:

A mulher era menor e mais fraca, entre ela e o homem havia uma diferença que ela não podia superar, uma diferença imposta pela natureza, a mais vergonhosa e humilhante que é possível na sociedade dos homens. Quando a dominaçáo da natureza é o verdadeiro objetivo, a inferioridade biológica será sempre o estigma por excelência, e a fraqueza impressa pela natureza a marca incitando à violência (ADORNO; HORKHEIMER, 1985, p. 231).

$\mathrm{Na}$ passagem, há novamente uma ambiguidade, na qual a crítica acaba ressaltando uma visão das diferenças entre os gêneros muito pautada no biológico. Por um lado, as diferenças físicas e biológicas entre homem e mulher são realçadas, sem problematizar o fato de que tais diferenças também passaram por processos sociais de significação. Por outro, a concepção de que é a "sociedade dos homens" que julga essa suposta "fraqueza" como vergonhosa e humilhante permite perceber que a violência resultante de tal julgamento é consequência do modo como a dominaçáo masculina se configurou, ao longo do processo civilizatório ocidental.

\section{UTOPIAS FEMINISTAS?}

Ao final desse breve percurso a respeito das reflexôes de Adorno e Horkheimer em relação às mulheres, principalmente em suas discussóes a respeito do esclarecimento, talvez valha a pena incluir algumas palavras a respeito de como e se é possível pensar alguma forma de resistência, diante desse quadro tão desolador. Afinal, se é necessário reconhecer que, no diagnóstico apresentado na Dialética do esclarecimento, de Adorno e Horkheimer, "não há vida certa na falsa” (ADORNO, 2008, p. 36) - como vai resumir Adorno, 
em Minima Moralia - também é verdade que, no percurso desse pensamento, foram sendo incluídas pequenas doses de utopia, que, se não apontam saídas definitivas, deixam transparecer ínfimas fendas de potencialidades, para que se deem os "ensaios inconscientes para a vida certa" (ADORNO, 2008, p. 225).

Com a intenção de procurar por essas pequenas brechas utópicas, retomo uma outra passagem de Minima Moralia, especificamente relativa à temática dessa proposta: "O caráter feminino e o ideal de caráter segundo o qual ele é modelado são produtos da sociedade masculina [...] Aquilo que no nexo universal de ofuscação burguês se diz natureza não passa da marca da ferida da mutilação social" (ADORNO, 2008, p. 91). O trecho resume bem as conclusôes que gostaria de sugerir, com base no que foi exposto acima, conforme argumenta Gabriel Cohn (2008, p. 253):

Cabe inteiramente atribuir o devido peso à preocupação de Adorno com a possibilidade ou não da vida justa, quando se considera que a figura do Outro como interlocutor pleno, em contraste com as condiçôes existentes de isolamento e mutismo dos indivíduos, percorre a obra de ponta a ponta como alusão central e persistente.

Também no caso da discussão relativa à mulher, na Dialética do esclarecimento, é possível notar essa preocupação acerca do cerceamento da possibilidade de uma "interlocutora plena", precisamente porque homens e mulheres estão enredados em processos de individualização calcados na dominação. Ao longo do texto, vimos que o caráter supostamente mais ligado à natureza que se delega às mulheres passa, na verdade, por uma deformação masculina da ideia de natureza. A natureza (seja interna, seja externa) é, para Adorno e Horkheimer, o domínio do não-idêntico, que é corrompido pelo "nexo socialmente culpado" [gesellschaftlischer Schuldzusammenhang]. A sociedade capitalista também dota de significado a natureza, conforme conteúdos reificados próprios da racionalidade instrumental. Nesse sentido, delegar às mulheres o domínio da natureza, recusar-lhes a "honra da individualização" e submetê-las ao domínio dos portadores por excelência da razão é a estratégia encontrada para a submissão delas, que, durante o processo de civilização do Ocidente, não se deixaram classificar totalmente em conformidade com a racionalidade instrumental. Para isso, há renúncias de ambos os lados (como vimos no episódio da Odisseia, relativo ao encontro entre Ulisses e Circe), mas a renúncia do homem reinscreve uma violência em direção às mulheres. 
Porém, por outro lado, se esse mecanismo serve para manter a dominação masculina, vislumbrado a partir de uma outra perspectiva, ele abre brecha para que permaneça, na identidade das mulheres, uma maior abertura para o domínio do indefinido, da pluralidade, do náoidêntico - ou, ao menos, para a capacidade de sentir a imposição de uma aproximação à natureza como "mutilação social" (ADORNO, 2008, p. 91). Se os autores da Dialética do esclarecimento negam a possibilidade de saídas emancipatórias restritas a determinados grupos, suas articulaçóes em torno de subjetividades dominadas (como mulheres, crianças e escravos) sugerem fortemente que a própria cunhagem identitária é uma violência da "cultura masculina” (ADORNO; HORKHEIMER, 1985, p. 233). Nesse sentido, talvez, como os autores escrevem em relaçáo aos animais, seja facultado às mulheres recordarem "uma desgraça infinita ocorrida em tempos imemoriais" (ADORNO; HORKHEIMER, 1985, p. 231). Trata-se da desgraça que sacrificou a pluralidade, no decorrer do processo civilizatório ocidental, em função da conformação de uma razão abstrata, normativa, a qual se esforça por dominar e domesticar toda natureza por meio da classificação.

Tal rememoração seria a maneira das mulheres de pôr em questão o esclarecimento, de fazer com que ele "acolh[a] dentro de si a reflexão" acerca de seu inexorável "elemento regressivo", de não deixar que esse esclarecimento sele "seu próprio destino". No registro feito por esses autores, não se trata, contudo, de abandonar a razão, mas de compreender seus momentos míticos, que incorporaram, historicamente, a dominação como elemento inerente. Assim, a mulher não seria necessariamente o outro da razão, mas sua constituição histórica poderia apontar um processo de individualização que não se deixou reduzir completamente à lógica identitária da razão instrumental masculina tendo em vista que "a mulher não é sujeito" (ADORNO; HORKHEIMER, 1985, p. 231) - e, nesse sentido, talvez elas possam trazer à tona as violências inerentes ao processo civilizatório ocidental.

As identidades subalternas, as quais se definem não como afirmaçóes de algo, mas muito mais como a negação de aspectos presentes em identidades dominantes, talvez possam portar implicitamente a capacidade de enfraquecer as bases pretensamente sólidas dos elementos que sustentam a relação de dominação existente sobre elas. No caso específico da dominação masculina, as mulheres, muitas vezes definidas apenas como o outro do indivíduo masculino, como não-indivíduos, não sujeitos, possuem sua maior potencialidade, não em uma afirmação unívoca e fixa de sua essência, mas, de fato, na denúncia 
da falácia desse sujeito universal, idêntico a si mesmo, que a racionalidade ocidental se esforçou a duras penas por construir.

É certo, porém, que, para fazermos jus à crítica ao esclarecimento presente no pensamento de Theodor Adorno e Max Horkheimer, é necessário reconhecer que não é simplesmente essa percepçáo subjetiva que será capaz de fazer desmoronar a dominação masculina, tendo em vista que não se pode ter "nenhuma emancipação sem a da sociedade." (ADORNO, 2008, p. 169).

SANTOS, P. S. Enlightenment and Masculine domination. Trans/form/ação, Marília, v. 43, n. 3, p. 313-334, Jul./Set., 2020.

\begin{abstract}
This article aims to interpret the book Dialectic of Enlightenment and its main arguments considering the masculine domination which permeates the modern rationality. In order to do this an interpretation about the intertwining between myth and enlightenment during the process of western civilization is suggested, indicating that the arguments of Adorno and Horkheimer take modernity as a fundamentally male project.
\end{abstract}

Keywords: Enlightenment. Civilization. Male domination. Nature.

\title{
REFERENCIAS
}

ADORNO, Theodor. Educaçáo e emancipaçáo. Tradução: Wolfgang Leo Maar. São Paulo: Paz e Terra, 2006.

ADORNO, Theodor W. e HORKHEIMER, Max. Dialética do esclarecimento. Tradução: Guido de Almeida. Rio de Janeiro: Jorge Zahar, 1985.

ADORNO, Theodor. Minima moralia. Tradução: Gabriel Cohn. Rio de Janeiro: Azougue, 2008.

BÄCHI, Beat. 2003. Georg Simmel und die Frauen: Macht - Körper - Wissen. Disponível em: http://socio.ch/sim/on_simmel/t_baechi.htm. Acesso em 10/01/2019.

BEAUVOIR, Simone de. O Segundo Sexo. v.I, II. Tradução Sérgio Milliet. Rio de Janeiro: Nova Fronteira, 1980.

BENHABIB, Seyla e CORNELL, Drucilla (org). Feminismo como crítica da modernidade. Rio de Janeiro: Rosa dos Tempos, 1987. 
BENHABIB, Seyla. Situating the Self: gender, community and postmodernism in contemporary ethics. New York: Routledge, 1992.

BUTLER, J. Merely Cultural. Social Text. vol. 15, n. 3-4, p. 265-277, 1997.

BUTLER, Judith. Problemas de gênero: feminismo e subversáo da identidade.

Tradução de Renato Aguiar. Rio de Janeiro: Civilização Brasileira, 2003.

COMMAY, Rebecca. Adorno's Siren Song. In: HEBERLE, Renée (org.). Feminist Interpretations of Theodor Adorno. Pennsylvania: The Pennsylvania State University Press, 2006, p. 41-67.

COHN, Gabriel. As diferenças finas: de Simmel a Luhmann. Revista brasileira de Ciências Sociais 13(38): 53-62, 1998.

COHN, Gabriel. Alguns problemas de leitura e tradução de Minima Moralia, in ADORNO, Theodor. Minima Moralia. Rio de Janeiro: Beco do Azougue, 2008.

FRASER, Nancy. Fortunes of feminism. From State-managed capitalism to neoliberal crisis. Londres, Nova Iorque: Verso, 2013.

FREUD, Sigmund. O mal-estar na cultura. Tradução: Renato Zwick. São Paulo: L\&PM, [1929] 2010.

FREUD, Sigmund. Psychoanalytische Bemerkungen über einen autobiographisch beschriebenen Fall von Paranoia (Dementia paranoides) In FREUD, Sigmund. Studienausgabe Band VII. Frankfurt a. M.: S. Fischer Verlag, [1911] 1973.

HEWITT, Andrew. A Feminine Dialectic of Enlightenment? Horkheimer and Adorno Revisited. In: HEBERLE, Renée (org.). Feminist Interpretations of Theodor Adorno. Pennsylvania: The Pennsylvania State University Press, 2006, p. 69-96.

HOMERO. “Canto X”; “Canto XII. In: Odisseia. Tradução Donaldo Schüler. Porto Alegre: L\&M Pocket, 2008.

Lichtblau, Klaus. Kulturkrise und Soziologie um die Jahrhundertwende. Zur Genealogie der Kultursoziologie in Deutschland. Frankfurt a. M.: Suhrkamp, 1996.

PATEMAN, Carole. O contrato sexual. Tradução Marta Avancini. São Paulo: Paz e Terra, 1993.

RÜHLE-GERSTEL, Alice. Die Frau und der Kapitalismus [A mulher e o capitalismo]. Frankfurt: Neue Kritik, [1932] 1972.

SCOTT, Joan Wallach. Gênero: uma categoria útil de análise histórica. Educação \& Realidade. Porto Alegre, vol. 20, no 2, jul./dez. 1995, p. 71-99.

SIMMEL, Georg. Weibliche Kultur [Cultura feminina]. In: SIMMEL, Georg. Gesamtausgabe, vol. 14. Frankfurt a. M.: Suhrkamp, [1902] 1995. 
SIMMEL. Die Rolle des Geldes in den Beziehungen der Geschlechter In: SIMMEL, Georg. Schriften zur Philosophie und Soziologie der Geschlechter. Frankfurer a. M.: Suhrkamp, [1898] 1985.

WIGGERSHAUS, Rolf. Die Frankfurter Schule. Munique: Deutscher Taschenbuch Verlag, 2008. 
SANTOS, P. S. 